\title{
A SEGMENTATION OF GEORGIAN POPULATION ACCORDING TO FINANCIAL RESOURCES AND A STYLE OF MONEY MANAGEMENT Vanishvili M.M. ${ }^{1}$, Chelidze M.E. ${ }^{2}$ (Georgia) Email: Vanishvili330@ scientifictext.ru
}

\author{
${ }^{I}$ Vanishvili Merab Mihailovich - D.Sc. in Economics, Professor; \\ ${ }^{2}$ Chelidze Medea Elishukovna - PhD in Economics, Associate Professor, \\ DEPARTMENT OF FINANCIAL AND BANKING TECHNOLOGIES, \\ GEORGIAN TECHNICAL UNIVERSITY, \\ TBILISI, GEORGIA
}

\begin{abstract}
Georgian population is segmented according to financial resources and a style of money management. The article is based on the newest references and rich factual materials.

Six segments of Georgian population are represented according to financial resources. These segments are grouped under three corresponding socioeconomic statuses. Last three segments are grouped under the socioeconomic status of financially adapted and it comprises $28.3 \%$ of Georgian population. Another two segments are grouped under the socioeconomic status of more or less financially adapted and it comprises $35.9 \%$ of Georgian population. The remaining segment, i.e. 32.4\% of Georgian population, has socioeconomic status of being into financial hardship.

We used 23 theses (related to a money management) for in-depth analysis of techniques of money management that are widely-spread in Georgian population. We analyzed conclusions of above-mentioned theses and identified the following 6 segments of Georgian population according to the style of money management: financially responsible (34\%); with financial fears (22\%); with business thinking (12\%); burdened with debts (16\%); wasteful (11\%) and "shopaholic" (5\%).

Keywords: socioeconomic status, financial responsibility, financial fears, business thinking, burdened with debts, wasteful, shopaholic.

\section{СЕГМЕНТАЦИЯ НАСЕЛЕНИЯ ГРУЗИИ ПО ФИНАНСОВЫМ ВОЗМОЖНОСТЯМ И СТИЛЮ УПРАВЛЕНИЯ ДЕНЕЖНЫМИ СРЕДСТВАМИ Ванишвили М.М.' ${ }^{1}$ Челидзе М.Э. ${ }^{2}$ (Грузия)}

\author{
${ }^{1}$ Ванишвили Мераб Михайлович - доктор экономических наук, профессор; \\ ${ }^{2}$ Челидзе Медея Элишуковна - кандидат экономических наук, ассоииированныіи профессор, \\ Департамент финансовых и банковских технологий, \\ Грузинский технический университет, \\ г. Тбилиси, Грузия
}

\begin{abstract}
Аннотация: в статье, на основании новейшей литературы и богатых фактических материалов, произведена сегментация населения Грузии по финансовым возможностям и стилю управления денежными средствами.

По финансовым возможностям представлены 6 сегментов населения Грузии, которые сгруппированы по трем соответствующим социо-экономическим статусам. В частности: последние 3 сегмента были сгруппированы под финансово адаптированный сочио-экономический статус и составляют $28.3 \%$ всего населения Грузии; еще 2 сегмента сгруппированы под финансово более или менее адаптированный соиио-экономический статус и составляют 35.9\% всего населения Грузии; 32.4\% населения Грузии переживают финансовые затруднения, данный сегмент оказался под финансово неудовлетворительным социо-экономическим статусом.

Для углубленного изучения путей управления денежными средствами, распространненного среди населения, были использованы 23 положения, связанных с управлением денежными средствами. На основании анализа полученных ответов были выделены 6 сегментов по стилю управления денежными средствами в Грузии: финансово ответственные (34\% населения), с финансовыми страхами (22\% населения), с деловым мышлением (12\% населения), обремененные долгами (16\% населения), расточительные (11\% населения) и «шопоголики» (5\% населения).
\end{abstract}

Ключевые слова: социо-экономический статус, финансовая ответственность, финансовые страхи, деловое мышление, обремененный долгом, расточительный, шопоголик.

Introduction: Individual's reasonable financial activity determines his/her financial condition in a short-term and a long-term perspective. Certain activities, such as delay of paying taxes or buying financial product without preliminary comparison, may negatively impact individual's financial condition and correspondingly, his/her financial welfare. Therefore, it is important to study population's financial activities and segment it according to financial resources and a style of money management. 
The current article is based on a data gathered in Georgia with participation of research organization "Sonari" [1] and with support from Development Facility of the European Fund for Southeast Europe (EFSE DF). The initiative belongs to Georgian National Bank. Data was gathered from a whole country by means of direct interviewing of 1100 respondents (with age above 18). A stratified cluster selection technique was used and selection was made according to types of regions and settlements (city/village). Points of selection were established in direct proportion to population and respondents were selected randomly from households on the basis of "principle of last birthday". Field works have been conducted from 1st April to 25th April of 2016. Data is weighted according to region, age and gender.

Methodology of a study is based on 2015 year guideline of estimation of financial education and financial participation. The guideline belongs to International Network of Financial Education of Organization of Economic Cooperation and Development (OECD/INFE) [2]. Survey of OECD/INFE includes questions of several types and helps us determine positive and negative financial activities of a population, such as consideration of several choices before buying a financial product, payment of taxes on time, budgeting, money saving and loans. Data gathered from Georgia is a part of a comparative international report of OECD/INFE from 2016 [3].

Study Results: In the scope of the study, six segments of population of Georgia were selected on the basis of financial resources:

- Barely live from month to month (32.4\% of population);

- Money is enough for food, but to buy clothes is a huge problem $(28.2 \%)$;

- It is hard to buy TV or refrigerator with our resources or credit $(17.7 \%)$;

- Money is enough to buy electric appliances, but we can't afford a new automobile (16.0\%);

- We can buy everything with our resources except country-house or flat $(9.8 \%)$;

- We don't have material difficulties and we can buy country-house or flat (2.5\%).

Afterwards, the above-mentioned segments were combined under the socioeconomic statuses:

The last three segments were grouped under the socioeconomic status of financially adapted, because these people can satisfy the basic demands, such as buying food or clothes. Besides, they have comparatively big consumer opportunities. This segment comprises $28.3 \%$ of Georgian population.

Another two segments have relatively limited consumer opportunities, but these people can also satisfy the basic demands somehow. So these two segments can be grouped under socioeconomic status of more or less financially adapted. They comprise $39.9 \%$ of Georgian population.

And finally, one third of Georgian population, i.e. $32.4 \%$ has financial difficulties. This segment was grouped under the socioeconomic status of being in financial hardship.

In the process of development of initiatives of financial education, interesting and practical ideas can be generated by means of population's segmentation according to a style of money management. For this purpose, our study used 23 theses related to money management. These theses help us study popular techniques of money management in details.

On the basis of analysis of conclusions of above-mentioned theses, we identified the following 6 segments of Georgian population according to the style of money management:

- financially responsible;

- with financial fears;

- with business thinking;

- burdened with debts;

- wasteful;

- "shopaholic"

Interestingly, the lowest scores of financial education are associated with segments of "shopaholic", wasteful and burdened with financial fears. Segment with financial fears has the most limited financial resources. Therefore, its experience (as consumer) is scarce. On the other side, wasteful and "shopaholic" respondents have experience of so-called "active expenses".

Financially responsible segment (34\% of population) is the most prevalent in Georgia. Then we have segments burdened with debts $(16 \%)$ and with financial fears $(22 \%)$.

Below we describe each segment in details.

Financially responsible segment. Respondents from this segment agree to the following theses:

- Pay taxes on time;

- Try to pay debt as soon as possible, because it disturbs me;

- Carefully consider whether a product is affordable before buying;

- Loan money only in the emergency situation;

- Money is hard to get, so it must be spent carefully;

- Thoroughly control and plan my finances. 
Financially responsible segment is the most prevalent in Georgia (34.3\%). Members of the corresponding segment are characterized with practical financial activities. They carefully spend money, control their finances. Besides, they have habit to meet their liabilities on time and skill to plan finances. This segment is less inclined to buy financial products. Loan liabilities are too disturbing for them and they try to free themselves from debts as soon as possible. $61 \%$ of this segment is comprised with women, average age is 47.6 , but most of them are above 65. Probability to meet them in Guria, Adjaria and Shida Kartli is high. In Kakheti and Qvemo Qartli, it is hard to find this segment and it is almost impossible in Samtskhe-Javakheti.

Financially responsible segment has a high score of financial education and it is 63.0 out of $100^{1}$ (Table 1).

Table 1. The general indicators of financial education of financially responsible segment

\begin{tabular}{|c|c|c|c|}
\hline Financial education & Financial activity & Financial attitude & $\begin{array}{c}\text { Financial education } \\
\text { (scale of 100 scores) }\end{array}$ \\
\hline \multicolumn{4}{|c|}{ Score } \\
\hline 4.71 & 5.37 & 3.15 & 58.8 \\
\hline
\end{tabular}

Segment with financial fears. Respondents of this segment agree to the following theses:

- I'm often nervous whether I can meet the current, basic financial demands;

- My financial condition doesn't allow me to make many things that are important for me.

It is interesting that the segment with financial fears is on the second place $(21.6 \%)$ in Georgia. This segment is characterized with scarce financial resources and sense of fear or insecurity towards the financial issues.

$53.4 \%$ of this segment lives in villages and it is a quite large proportion if we take into account that in reality only $43 \%$ of Georgian population lives in villages. Average age of this segment is 46.1 and also most of respondents with age group 56-65 belong to the same segment. Besides, majority of this segment is unemployed and most of them live in Samtskhe-Javakheti, Kakheti and Qvemo Qartli. In Tbilisi and Imereti, share of this segment is below average. Share of women is above average in this segment, as well as in the financially responsible segment.

Score of financial education of segment with financial fears is below average and comprises 56.2 out of 100 (Table 2).

Table 2. The general indicators of financial education of the segment with financial fears

\begin{tabular}{|c|c|c|c|}
\hline Financial education & Financial activity & Financial attitude & $\begin{array}{c}\text { Financial education } \\
\text { (scale of 100 scores) }\end{array}$ \\
\hline \multicolumn{5}{|c|}{ Score } \\
\hline 4.26 & 4.52 & 3.02 & 56.2 \\
\hline
\end{tabular}

Segment with business thinking: Respondents of this segment agree to the following theses:

- I have long-term financial aims and I try to achieve them;

- I always distribute monthly income to make some saving even if it's not very big;

- I'm ready for minor risks, when I gather money or make some investment.

Segment with business thinking comprises only $11.7 \%$ of population. Average age of this segment is the lowest and comprises 41.1. Balance of age groups is disturbed and inclined towards the age group 18-45. Therefore, probability to meet age group 18-45 in this segment is significantly higher than average. In this segment it is almost impossible to meet individuals above 66.

Men with business thinking are more than women in the country. Most frequently you will meet this segment in Tbilisi (37.7\%), then we have Qvemo Qartli (12.3\%) and Samegrelo (11.5\%). Probability to meet this segment in Qartli, Adjaria and Mtskheta-Mtianeti is low and in Guria such probability is almost equal to zero. Individual with business thinking distributes his/her income such that it is possible to make some savings. His/her financial plans are long-term and he/she doesn't fear reasonable risks. Correspondingly, this segment is the most stable financially.

Segment with business thinking has the biggest score of financial education, particularly 65.5 out of 100 (Table 3).

Table 3. The general indicators of financial education of the segment with business thinking

\begin{tabular}{|c|c|c|c|}
\hline Financial education & Financial activity & Financial attitude & $\begin{array}{c}\text { Financial education } \\
\text { (scale of 100 scores) }\end{array}$ \\
\hline \multicolumn{6}{|c|}{ Score } \\
\hline 4.89 & 6.19 & 2.69 & 65.6 \\
\hline
\end{tabular}

Segment burdened with debts. Respondents of this segment agree to the following theses:

\footnotetext{
${ }^{1}$ Financially responsible segment is on the second place after segment with business thinking according to this indicator.
} 
- At this moment I have excessive debts;

- I need debts for self-support from wage to the wage;

- I always try to distribute monthly income, but in spite of this, I spent everything senselessly.

This segment is burdened with debts and barely lives from wage to wage. Besides, it is hard to manage scarce financial resources in spite of repeated attempts. $80 \%$ of this segment has the current loan. If we take into account a type of settlement and gender, this group is close to average, but the main differences are age and regional distribution. In this segment, number of individuals above 66 and from age group 18-25 is significantly lower that average. However, share of age group 36-55 is more than average. If we take into account a region, then this segment mainly lives in Mtskheta-Mtianeti, Shida Qartli and Samtskhe-Javakheti.

The score of financial education of the segment burdened width debts is lower than country's average and comprises 57.7 out of 100 (Table 4.)

Table 4. The general indicators of financial education of the segment burdened with debts

\begin{tabular}{|c|c|c|c|}
\hline Financial education & Financial activity & Financial attitude & $\begin{array}{c}\text { Financial education } \\
\text { (scale of 100 scores) }\end{array}$ \\
\hline \multicolumn{4}{|c|}{ Score } \\
\hline 4.49 & 4.79 & 2.84 & 57.7 \\
\hline
\end{tabular}

Wasteful segment. Respondents of this segment agree to the following theses:

- It is more pleasant for me to spend money, than to save it for the long-term purposes;

- I live for today and think less about tomorrow;

- Money is for spending.

Young people (from age group 18-25) are often representatives of this segment and share of men is significantly higher than women. If we take into account a region, then representatives of this segment often live in Tbilisi and Samegrelo. Probability to meet this people in Shida Qartli or Samtskhe-Javakheti is almost equal to zero.

Wasteful segment thinks that it must live for pleasure and money is made for this purpose. Representatives of this segment live for today, think less about tomorrow and orient on short-term goals. Therefore, this segment seldom saves any money.

The score of financial education of wasteful segment is the lowest and comprises 49.2 out of 100 (Table 5).

Table 5. The general indicators of financial education of the wasteful segment

\begin{tabular}{|c|c|c|c|}
\hline Financial education & Financial activity & Financial attitude & $\begin{array}{c}\text { Financial education } \\
\text { (scale of 100 scores) }\end{array}$ \\
\hline \multicolumn{4}{|c|}{ Score } \\
\hline 4.43 & 4.19 & 1.70 & 49.2 \\
\hline
\end{tabular}

"Shopaholic" segment. Respondents of this segment agree to the following theses:

- Sometimes I buy things spontaneously, unexpectedly and only lately I understand that it wasn't affordable for me;

- It irritates me, when people constantly distribute and count money;

- If I wish something too much, I will lend money;

"Shopaholic" segment is a wasteful in its nature. "Shopaholics" prefer consumer needs over financial resources, lend money to satisfy their desires, make spontaneous decisions when buying products and people, who always distribute and count money, are irritating for them. Wasteful segment is oriented on spending money, but "shopaholics" are concentrated on the particular consuming temptations. It is interesting that share of men is once again higher in this segment. If we take into account an age group, number of respondents from age group 18-35 is higher than average, but number of respondents from age group 56-65 is small. Basically we can meet this segment in Samtskhe-Javakheti, Samegrelo, Qvemo Qartli, Guria and partially Imereti. Probability to find this segment in Mtskheta-Mtianeti and Shida Qartli is almost equal to zero. In difference from wasteful segment, share of "shopaholics" from Tbilisi is lower than in other segments.

The score of financial education of "shopaholics" is quite low and comprises 50.2 out of 110 (Table 6).

Table 6. The general indicators of financial education of the "shopaholic" segment

\begin{tabular}{|c|c|c|c|}
\hline Financial education & Financial activity & Financial attitude & $\begin{array}{c}\text { Financial education } \\
\text { (scale of 100 scores) }\end{array}$ \\
\hline \multicolumn{4}{|c|}{ Score } \\
\hline 3.99 & 3.82 & 2.74 & 50.2 \\
\hline
\end{tabular}


Conclusion: Data accumulated as a result of the study is important for development of certain standards and indicators of population's financial activity, as well as for development and implementation of particular programs in the scope of national strategy of financial activity.

Responsible activities, such as paying taxes on time and consideration of financial resources before buying any product, are widely-distributed in population, but often we meet activities that have undesirable financial results.

Consumer must have habit to make private and household budget, as well as it is important to make savings and develop long-term aims. Financial decisions must be part of generalized financial plan and not spontaneous or unadvised activities.

There is positive dependence between healthy culture of saving and financial welfare. Population without culture of saving often gets in a situation, when new loan is necessary to redeem another one.

Special means are necessary to support beneficial financial activities and gather reliable or comparative data. Such means may be resource centers, web portals and mobile channels. Besides, it is recommended to launch campaigns about benefits of savings, as well as develop and distribute mechanisms to support savings.

\section{References / Список литературы}

1. The report of study about financial education and participation / The report is prepared by LTD "Sonari" by order of National Bank of Georgia / The methodology of study is developed by International Network of Financial Education of Organization of Economic Cooperation and Development (OECD/INFE) / The project was implemented with support of Development Facility of the European Fund for Southeast Europe (EFSE DF). [Electronic resource]. November, 2016. Georgia. URL: https://www.nbg.gov.ge/uploads/2016finganat/ Financial\%20Literacy\%20Study_GEO.pdf/ (date of access: 30.05.2017).

2. OECD/INFE (2015), „2015 OECD/INFE Toolkit for Measuring Financial Literacy and Financial Inclusion“, OECD, Paris. [Electronic resource]. URL: http://www.oecd.org/daf/fin/financialeducation/2015_OECD_INFE_Toolkit_Measuring_Financial_Literacy.pdf/ (date of access: 30.05.2017).

3. OECD/INFE (2016). „OECD/INFE International Survey of Adult Financial Literacy Competencies“. [Electronic resource]. URL: http://www.oecd.org/daf/fin/financial-education/OECD-INFE-InternationalSurvey-of-Adult-FInancial-Literacy-Competencies.pdf/ (date of access: 29.05.2017).

4. The Legatum Prosperity Index [Electronic resource], 2015. URL: http://www.prosperity.com/ (date of access: 30.05 .2017$)$.

5. Atkinson A. and Messy F.,2012. „Measuring Financial Literacy: Results of the OECD / International Network on Financial Education (INFE) Pilot Study“, OECD Working Papers on Finance, Insurance and Private Pensions. № 15. OECD Publishing, Paris. [Electronic resource]. URL: http://dx.doi.org/10.1787/5k9csfs90fr4-en/ (date of access: 27.05.2017). 